ISPEC Tarım Bilimleri Dergisi

$2020: 4(4)$

(C) Telif hakk ISPEC'e aittir

Arasturma Makalesi

\section{*Omar MARDENLI}

Orcid No: 0000-0002-6092-7604

*Faculty of Agriculture, University of Aleppo, SYRIA

omardenli@gmail.com

\section{DOI}

https://doi.org/10.46291/ISPECJASv ol4iss4pp732-746

Geliş Tarihi: $01 / 10 / 2020$

Kabul Tarihi: 25/10/2020

\section{Keywords}

Follicle size, glucose, hormones, insulin-like growth factor, nuclear maturation, sheep

\title{
www.ispecjournal.com
}

\author{
Role of Follicle Size, IGF-I, Glucose and Hormones on \\ Nuclear Maturation Events of Awassi Sheep Oocytes \\ (Ovis aries)
}

\section{Abstract}

This experiment aimed to study the combined effect of each of the follicle size, insulin-like growth factor (IGF-I), glucose and hormones (growth hormone (GH) and luteinizing hormone ( $\mathrm{LH})$ ) on different phases of in vitro nuclear maturation of Awassi sheep oocytes. Follicles diameters were divided into two main groups: small follicles (SF): 1-2 mm and large follicles (LF): $>2 \mathrm{~mm}$. The levels $(\mu \mathrm{g} / \mathrm{ml})$ of Insulin-Like Growth Factor (IGF-I), GH, LH and glucose $(\mathrm{mM})$ were determined according to two increasing shared concentrations (A:5,5,1 and 50; B:10,5.5,5 and 100 respectively). The maturation events were monitored at 7 -time intervals $(0,3,6,9,12,21$ and 27 hours). Before incubation ( 0 - hour time interval), the oocytes in SF group outperformed their counterparts of LF group in the germinal vesicle phase $(92.45 \%$ Vs $74.46 \%$; $\mathrm{p}=0.01$ ). Down to the 6- hour time interval, the oocytes in B solution achieved the highest rates (24.52\%; LF group), After 9 hours of incubation, the differences appeared clearly in the prometaphase $-1(\mathrm{p}=0.05)$ as half of the number of oocytes in $\mathrm{B}$ solution reached the stage (53.84\%; LF group), the rates did not exceed $31.37 \%$ (A solution; SF group). In the 12 - hour time interval, the pro -metaphase-1 rates across the four groups reached the values: $34.00 \%$ (A solution; SF group), $40.00 \%$ (B solution; LF group), 53.84\% (A solution; SF group) and 58.49\% (B solution; LF group) respectively. Upon 21- hour time interval, oocytes across the different groups showed a significant difference in metaphaseI ( $p=0.01)$ with the superiority of oocytes of B solution $(33.96 \%$; LF group). At the 24- hour time interval, the rates of oocytes involved in the metaphase-II were sub-intermediate and ranged between $20.00 \%$ and $36.00 \%$ without statistical significance. The final time interval (27- hours of incubation) showed a significant difference in the rates of the metaphase-II $(\mathrm{p}=0.002)$, as the oocytes of B solution showed a great superiority ( $84.61 \%$; LF group). It is concluded from this study that the maturation of oocytes derived from large follicles (>2 mm) in a mixture of IGF-I, GH, $\mathrm{LH}(\mu \mathrm{g} / \mathrm{ml})$ and glucose $(\mathrm{mM})$ with the levels 10,5.5,5 and 100 respectively led to a significant increase in the rates of metaphase-II. 


\section{INTRODUCTION}

Within the literature of assisted reproductive technology (ART), principles and parameters of oocytes maturation theories, several studies have assumed that both types of maturation (cytoplasmic and nuclear forms) is governed by a very complex set of factors, variables and events. Those studies have been concerned with the phenomenon of oocyte arrest, release and follicle degradation (atresia). It was found that these phenomena are affected by many factors, for example, but not limited to: the levels of intracellular cyclic adenosine monophosphate (cAMP), cell cycle proteins (Maturation Promoting Factors-MPF), cAMP-activated protein kinase A(PKA), epidermal growth factor (EGF), steroids, gap junctions, guanine nucleotidebinding proteins (G-proteins), phosphodiesterase (PDE) and mitogenactivated protein kinase (MAPK or MAP kinase) ( Sen and Caiazza, 2013). It is well known that gonadotropin hormones (FSH and LH) are very important in the development of ovarian follicles and granulosa cells, as well as the cytoplasmic and nuclear maturation of oocytes. So, the synchronous relationship between these two hormones will lead to a set of certain events (e.g. ovulation, estradiol and progesterone production) that ultimately result in oocytes that are eligible for fertilization and subsequent embryonic divisions. InsulinLike Growth Factor is one of the growth factors that found naturally in the blood. It manages the effects of growth hormone $(\mathrm{GH})$ in the body and promotes oocyte maturation in many mammalian species (Driancourt and Thuel, 1998; Arat, 2016). Other studies have been demonstrated that IGF-1 promotes the maturation of bovine oocytes and swelling of cumulus cells (Lorenzo et al. 1994), inhibit apoptosis (Wasielak and Bogacki, 2007) and improves in vitro oocyte maturation, fertilization, and embryo development down to the blastocyst stage in mice (Toori et al. 2014). The study of Oberlender et al. (2013) showed that the addition of IGF-1 to IVM medium also increased the IVM and IVF rates in a porcine oocyte. Few studies have indicated the important vital role of glucose as an essential energy source in the processes of nuclear maturation of oocytes. Both meiosis resumption (Downs et al. 1996; Cetica et al. 2002) and the progression of meiosis to metaphase II stage (Steeves and Gardner, 1999; Spindler et al. 2000) is associated with increased glucose metabolism (GM) through one or more pathways; however, although there have 
been many reports on the effect of GM on oocyte nuclear maturation (Sato et al. 2007).

\section{MATERIALS and METHODS}

This experiment was conducted at the Reproductive Biotechnology Laboratory under the Department of Animal Production, Aleppo University. Except where otherwise indicated, all chemicals were purchased from the Sigma (St Louis, MO, USA).

\section{Animals and ovaries collection}

The ovaries were collected from healthy Awassi ewes, their ages ranged from 2 to 5 years; during the reproductive season (breeding season) from the local slaughterhouse of Aleppo City. The ovaries were kept in a thermos containing $0.9 \%$ physiological saline at $35{ }^{\circ} \mathrm{C}$ to $39{ }^{\circ} \mathrm{C}$ and transported to the laboratory within 1 hour of slaughter.

\section{Oocytes harvesting and evaluation}

The oocytes were collected by aspiration and slicing methods as described in previously by the author (Mardenli et al. 2020a; Mardenli et al. 2020b). A $10 \mathrm{ml}$ syringe attached with a needle (18 G) was loaded with Dulbecco's - phosphate buffer saline (DPBs), put in the ovarian parenchyma near the vesicular follicles and all follicles were aspirated. The slicing method was done by a certain blade. Morphologically healthy oocytes were selected (with evenly granulated cytoplasm surrounded by more than three layers of unexpanded cumulus cells (COCs). All anomalies with one of the following characteristics were excluded:

1-Oocytes that showed the presence of bubbles within the cytoplasm.

2-Oocytes with a cracked zona pellucida.

3-Completely naked oocytes of cumulus cells.

4-Oocytes with lysed cytoplasm.

5-Oocytes with retracted cytoplasm.

6-Free of cytoplasm oocytes.

\section{Follicles sizes determination}

Follicles diameters were measured by a certain ruler and divided into two main groups: small follicles (SF): 1-2 mm and large follicles (LF): >2 mm.

\section{IGF-I, glucose and hormones levels determination}

The levels of IGF-I, glucose and hormones were determined according to two increasing concentrations, as shown in the following table (Table 1): 
Table 1. Levels of IGF-I, glucose and hormones specified for in vitro maturation of Awassi sheep oocytes

\begin{tabular}{|c|c|c|c|c|}
\hline Treatment & IGF $(\mu \mathrm{g} / \mathrm{ml})$ & Glucose $(\mathrm{mM})$ & $\mathrm{GH}(\mu \mathrm{g} / \mathrm{ml})$ & $\mathrm{LH}(\mu \mathrm{g} / \mathrm{ml})$ \\
\hline A & 5 & 5 & 1 & 50 \\
\hline B & 10 & 5.5 & 5 & 100 \\
\hline
\end{tabular}

\section{IVM and time intervals}

The treatments were added to the culture media (TCM-199) supplemented with $10 \%$ fetal calf serum (FCS) and $50 \mu \mathrm{g} / \mathrm{ml}$ gentamycin sulfate, IVM was done as described elsewhere by de Oliveira Bezerra et al. (2019) with some modifications. Briefly, every 15-20 oocytes were transferred to wells and incubated at $38.5^{\circ} \mathrm{C}$ $\begin{array}{llll}\text { with } & 5 \% & \mathrm{CO}_{2} & \text { and saturated humidity }\end{array}$ according to the following time intervals: $0,3,6,9,12,21,24$ and 27 hours.

\section{Assessment of nuclear maturation}

During incubation, and according to the time intervals of incubation for each group of oocytes, the oocytes were denuded by vortexing them for $3 \mathrm{~min}$ and placed on separate clean dry glass slides. In order to fix the oocytes, the slides were immersed in a solution consisted of acetic acid and ethanol $(1: 3)$. Next, the oocytes were washed with $70 \%$ ethanol and stained with $1 \%$ orcein for $10 \mathrm{mi}$. Following staining, the oocytes were washed with a solution consisted of glycerol, acetic acid and water $(1: 1: 3)$ and examined under a phasecontrast microscope at x 400 .
Meiosis phases were monitored and recorded according to the specified time intervals.

\section{Statistical analyses}

After arranging the data (Microsoft Excel sheet) using a sophisticated computer, the data were analyzed by applying Pearson Chi-square of contingency tables in SAS Institute Inc. (2017) statistical package. The rates of different traits were presented as a percentage (\%) and compared according to the Fisher exact test for each trait.

\section{RESULTS}

1-The meiotic progression at the 0 - hour time interval In the two groups of oocytes that were stained immediately after collection, a significant difference was observed for the two phases ( $\mathrm{GV}$ and GVBD), where the oocytes grouped in SF group outperformed their counterparts of LF group in the GV phase $(92.45 \% \mathrm{Vs}$ $74.46 \% ; \mathrm{p}=0.01$ ). Conversely, GVBD rates were higher at oocytes collected from LF group (25.53\% Vs $7.54 \%$; $=0.01$ ) (Table 2). 
Table 2. The meiotic progression of Awassi sheep oocytes at the 0- hour time interval

\begin{tabular}{|c|c|c|c|c|c|c|c|c|c|c|c|c|}
\hline \multicolumn{2}{|c|}{ Source } & \multirow{2}{*}{$\begin{array}{c}\text { Incubated } \\
\text { oocytes } \\
\text { No. }\end{array}$} & \multicolumn{10}{|c|}{ The phase of nuclear maturation } \\
\hline Follicle size & $\begin{array}{c}\text { Maturation } \\
\text { treatment }\end{array}$ & & \multicolumn{2}{|c|}{$\begin{array}{c}\text { G.V } \\
(\text { No. } / \%)\end{array}$} & \multicolumn{2}{|c|}{$\begin{array}{c}\text { GVBD } \\
(\text { No. } / \%)\end{array}$} & \multicolumn{2}{|c|}{$\begin{array}{c}\text { Pro M-I } \\
(\text { No. / \%) }\end{array}$} & \multicolumn{2}{|c|}{$\begin{array}{c}\text { M-I } \\
\text { (No. / \%) }\end{array}$} & \multicolumn{2}{|c|}{$\begin{array}{c}\text { M-II } \\
(\text { No. } / \%)\end{array}$} \\
\hline SF & - & 53 & 49 & $92.45^{\mathrm{a}}$ & 4 & $7.54^{\mathrm{a}}$ & 0 & 0 & 0 & 0 & 0 & 0 \\
\hline $\mathrm{LF}$ & - & 47 & 35 & $74.46^{\mathrm{b}}$ & 12 & $25.53^{\mathrm{b}}$ & 0 & 0 & 0 & 0 & 0 & 0 \\
\hline \multicolumn{3}{|c|}{$\mathrm{P}$} & \multicolumn{2}{|c|}{0.01} & \multicolumn{2}{|c|}{0.01} & & & & & \\
\hline
\end{tabular}

SF: small follicles group, LF: large follicles group. Values for the same column with different letters are significantly different $(\mathrm{P}<0.05)$

\section{2- The meiotic progression at the 3-hour} time interval

Across the two groups of follicles and within the fourth treatments, although there were significant differences in the GV and GVBD phases rates, these rates remained very similar to the rates at the 0 -hour time interval. It is noticed that the oocytes incubated in B solution (LF group) showed the lowest rates of the $\mathrm{GV}$ phase $(71,69 \%$; $\mathrm{P}=0.03$ ) while the oocytes incubated in solution A (SF group) showed the lowest rates of the GVBD phase $(10.00 \% ; p=0.03)$ (Table 3).

Table. 3. The meiotic progression of Awassi sheep oocytes in vitro cultured for 3 hours in TCM-199 according to the follicle size and maturation treatment

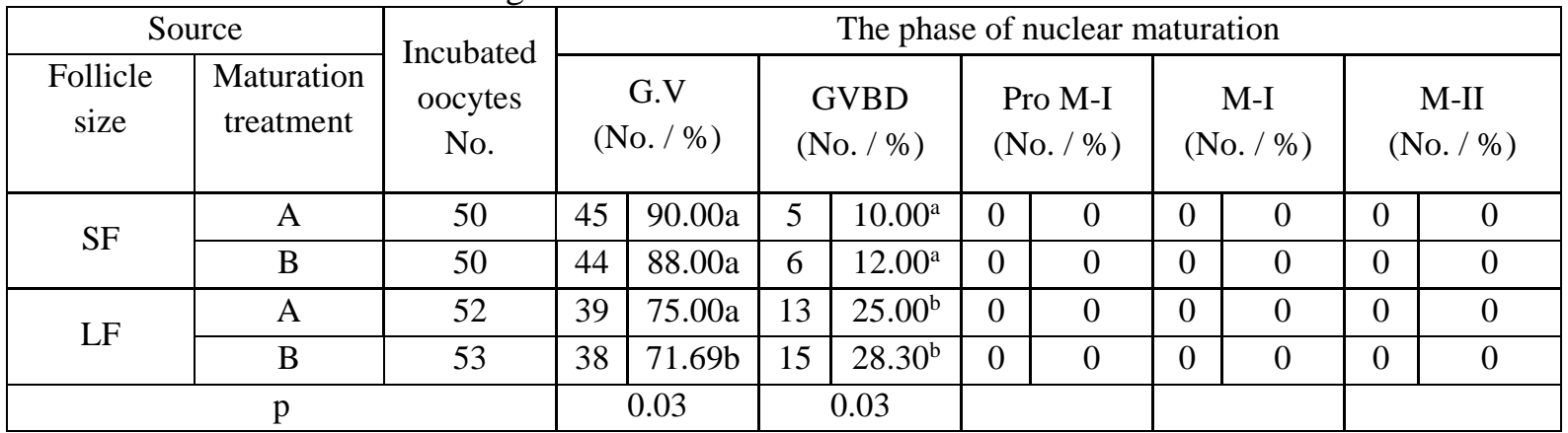

SF: small follicles group, LF: large follicles group. A: $5 \mu \mathrm{g} / \mathrm{ml} \mathrm{IGF+} 5 \mathrm{mM}$ Glucose $+1 \mu \mathrm{g} / \mathrm{ml} \mathrm{GH}+50 \mu \mathrm{g} / \mathrm{ml} \mathrm{LH}, \mathrm{B}: 10 \mu \mathrm{g} / \mathrm{ml}$ IGF+ $5.5 \mathrm{mM}$ Glucose $+5 \mu \mathrm{g} / \mathrm{ml} \mathrm{GH}+100 \mu \mathrm{g} / \mathrm{ml} \mathrm{LH}$. Values for the same column with different letters are significantly different $(\mathrm{P}<0.05)$.

\section{3- The meiotic progression at the 6- hour}

\section{time interval}

In this time interval, the presence of pro M-

1 was observed in the four groups but without significant superiority. However, the matured oocytes in B solution achieved the highest rates (24.52\%; LF group), while the lowest rates were at the matured oocytes in A solution (14.28\%; SF group). On the other hand, the significant differences remained in the GV and GVBD phases (Table 4). 
Table 4. The meiotic progression of Awassi sheep oocytes in vitro cultured for 6 hours in TCM-199 according to the follicle size and maturation treatment

\begin{tabular}{|c|c|c|c|c|c|c|c|c|c|c|c|c|}
\hline \multicolumn{2}{|c|}{ Source } & \multirow{2}{*}{$\begin{array}{c}\text { Incubated } \\
\text { oocytes } \\
\text { No. }\end{array}$} & \multicolumn{10}{|c|}{ The phase of nuclear maturation } \\
\hline $\begin{array}{c}\text { Follicle } \\
\text { size }\end{array}$ & $\begin{array}{c}\text { Maturation } \\
\text { treatment }\end{array}$ & & \multicolumn{2}{|c|}{$\begin{array}{c}\text { G.V } \\
\text { (No. } / \% \text { ) }\end{array}$} & \multicolumn{2}{|c|}{$\begin{array}{c}\text { GVBD } \\
(\text { No. } / \%)\end{array}$} & \multicolumn{2}{|c|}{$\begin{array}{l}\text { Pro M-I } \\
(\text { No. / \%) }\end{array}$} & \multicolumn{2}{|c|}{$\begin{array}{c}\text { M-I } \\
\text { (No. /\%) }\end{array}$} & \multicolumn{2}{|c|}{$\begin{array}{c}\text { M-II } \\
(\text { No. / \%) }\end{array}$} \\
\hline \multirow{2}{*}{ SF } & A & 49 & 27 & $55.10^{\mathrm{b}}$ & 15 & $30.61^{\mathrm{a}}$ & 7 & 14.28 & 0 & 0 & 0 & 0 \\
\hline & B & 54 & 28 & $43.75^{\mathrm{a}}$ & 17 & $31.48^{\mathrm{a}}$ & 9 & 16.66 & 0 & 0 & 0 & 0 \\
\hline \multirow{2}{*}{ LF } & A & 51 & 15 & $29.41^{\mathrm{a}}$ & 26 & $50.98^{\mathrm{b}}$ & 10 & 19.60 & 0 & 0 & 0 & 0 \\
\hline & B & 53 & 12 & $22.64^{\mathrm{c}}$ & 28 & $52.83^{\mathrm{b}}$ & 13 & 24.52 & 0 & 0 & 0 & 0 \\
\hline \multicolumn{3}{|c|}{$\mathrm{P}$} & \multicolumn{2}{|c|}{0.003} & \multicolumn{2}{|c|}{0.02} & \multicolumn{2}{|c|}{ NS } & & & & \\
\hline
\end{tabular}

SF: small follicles group, LF: large follicles group. A: $5 \mu \mathrm{g} / \mathrm{ml} \mathrm{IGF}+5 \mathrm{mM}$ Glucose $+1 \mu \mathrm{g} / \mathrm{ml} \mathrm{GH}+50 \mu \mathrm{g} / \mathrm{ml} \mathrm{LH}, \mathrm{B}: 10 \mu \mathrm{g} / \mathrm{ml}$ IGF+ $5.5 \mathrm{mM}$ Glucose $+5 \mu \mathrm{g} / \mathrm{ml} \mathrm{GH}+100 \mu \mathrm{g} / \mathrm{ml} \mathrm{LH}$. Values for the same column with different letters are significantly different $(\mathrm{P}<0.05)$. NS: not significant.

\section{4- The meiotic progression at the 9- hour time interval}

After 9 hours of incubation, the differences appeared clearly in the pro M-1 ( $\mathrm{p}=0.05)$, as half of the number of matured oocytes in solution B reached this stage (53.84\%; LF group), while the rates did not exceed
$31.37 \%$ at the matured oocytes in A solution (SF group). The presence of M-1 was observed in the four groups without significant differences, the rates ranged between $11.76 \%$ (A solution; SF group) and 23.07\% (B solution; LF group) (Table 5).

Table 5. The meiotic progression of Awassi sheep oocytes in vitro cultured for 9 hours in TCM-199 according to the follicle size and maturation treatment

\begin{tabular}{|c|c|c|c|c|c|c|c|c|c|c|c|c|}
\hline \multicolumn{2}{|c|}{ Source } & \multirow{2}{*}{$\begin{array}{c}\text { Incubated } \\
\text { oocytes } \\
\text { No. }\end{array}$} & \multicolumn{10}{|c|}{ The phase of nuclear maturation } \\
\hline $\begin{array}{c}\text { Follicle } \\
\text { size }\end{array}$ & $\begin{array}{c}\text { Maturation } \\
\text { treatment }\end{array}$ & & \multicolumn{2}{|c|}{$\begin{array}{c}\text { G.V } \\
(\text { No. } / \%)\end{array}$} & \multicolumn{2}{|c|}{$\begin{array}{c}\text { GVBD } \\
(\text { No. /\%) }\end{array}$} & \multicolumn{2}{|c|}{$\begin{array}{c}\text { Pro M-I } \\
(\text { No. / \%) }\end{array}$} & \multicolumn{2}{|c|}{$\begin{array}{c}\text { M-I } \\
(\text { No. /\%) }\end{array}$} & \multicolumn{2}{|c|}{$\begin{array}{c}\text { M-II } \\
(\text { No. / \%) }\end{array}$} \\
\hline \multirow{2}{*}{ SF } & A & 51 & 14 & $27.45^{\mathrm{a}}$ & 15 & 29.41 & 16 & $31.37^{\mathrm{a}}$ & 6 & 11.76 & 0 & 0 \\
\hline & B & 50 & 13 & $26.00^{\mathrm{a}}$ & 13 & 26.00 & 17 & $34.00^{\mathrm{a}}$ & 7 & 14.00 & 0 & 0 \\
\hline \multirow{2}{*}{$\mathrm{LF}$} & $\mathrm{A}$ & 51 & 5 & $9.80^{\mathrm{b}}$ & 10 & 19.60 & 25 & $49.01^{\mathrm{a}}$ & 11 & 21.56 & 0 & 0 \\
\hline & B & 52 & 5 & $9.61^{b}$ & 7 & 16.66 & 26 & $53.84^{b}$ & 12 & 23.07 & 0 & 0 \\
\hline \multicolumn{3}{|c|}{$\mathrm{p}$} & \multicolumn{2}{|c|}{0.01} & \multicolumn{2}{|r|}{ NS } & \multicolumn{2}{|c|}{0.05} & \multicolumn{2}{|c|}{ NS } & & \\
\hline
\end{tabular}

SF: small follicles group, LF: large follicles group. A: $5 \mu \mathrm{g} / \mathrm{ml} \mathrm{IGF+} 5 \mathrm{mM}$ Glucose $+1 \mu \mathrm{g} / \mathrm{ml} \mathrm{GH}+50 \mu \mathrm{g} / \mathrm{ml} \mathrm{LH}, \mathrm{B}: 10 \mu \mathrm{g} / \mathrm{ml}$ IGF+ $5.5 \mathrm{mM}$ Glucose $+5 \mu \mathrm{g} / \mathrm{ml} \mathrm{GH}+100 \mu \mathrm{g} / \mathrm{ml} \mathrm{LH}$. Values for the same column with different letters are significantly different $(\mathrm{P}<0.05)$. NS: not significant.

\section{5- The meiotic progression at the 12- hour}

\section{time interval}

In the 12 - hour time interval of incubation, as for pro $\mathrm{M}-1$, the differences became clearer $(\mathrm{p}=0.04)($ Table 6). This variability was accompanied by a slight increase in the M-I across the for groups of oocytes compared to the oocytes in the 9-hour time 
interval. In general,

the pro M-1 rates across the four groups were reached the values: $34.00 \%$ (A solution; SF group), $40.00 \%$ (B solution; LF group), 53.84\% (A solution; SF group) and $58.49 \%$ (B solution; LF group) respectively. On the other hand, the difference among $\mathrm{M}-1$ rates across the previous groups did not exceed $14.30 \%$. Also, a significant decrease in the rates of GV ( $p=0.01)$ and GVBD ( $p=0.03)$ was observed at matured oocytes in B solution $(30.77 \%$ and $9.43 \%$ respectively; LF group).

Table 6. The meiotic progression of Awassi sheep oocytes in vitro cultured for 12 hours in TCM-199 according to the follicle size and maturation treatment

\begin{tabular}{|c|c|c|c|c|c|c|c|c|c|c|c|c|}
\hline \multicolumn{2}{|c|}{ Source } & \multirow{2}{*}{$\begin{array}{c}\text { Incubated } \\
\text { oocytes } \\
\text { No. }\end{array}$} & \multicolumn{10}{|c|}{ The phase of nuclear maturation } \\
\hline Follicle size & $\begin{array}{c}\text { Maturation } \\
\text { treatment }\end{array}$ & & \multicolumn{2}{|c|}{$\begin{array}{c}\text { G.V } \\
(\text { No. / \%) }\end{array}$} & \multicolumn{2}{|c|}{$\begin{array}{c}\text { GVBD } \\
(\text { No. / \%) }\end{array}$} & \multicolumn{2}{|c|}{$\begin{array}{c}\text { Pro M-I } \\
(\text { No. } / \%)\end{array}$} & \multicolumn{2}{|c|}{$\begin{array}{c}\text { M-I } \\
(\text { No. / \%) }\end{array}$} & \multicolumn{2}{|c|}{$\begin{array}{c}\text { M-II } \\
\text { (No. / \%) }\end{array}$} \\
\hline \multirow{2}{*}{ SF } & $\mathrm{A}$ & 50 & 12 & $24.00^{\mathrm{b}}$ & 14 & $28.00^{\mathrm{a}}$ & 17 & $34.00^{\mathrm{a}}$ & 7 & 14.00 & 0 & 0 \\
\hline & B & 50 & 9 & $18.00^{\mathrm{a}}$ & 13 & $26.00^{\mathrm{a}}$ & 20 & $40.00^{b}$ & 8 & 16.00 & 0 & 0 \\
\hline \multirow{2}{*}{$\mathrm{LF}$} & $\mathrm{A}$ & 52 & 5 & $9.61^{\mathrm{a}}$ & 7 & $13.46^{\mathrm{a}}$ & 28 & $53.84^{b}$ & 12 & 23.07 & 0 & 0 \\
\hline & B & 53 & 2 & $3.77^{\mathrm{c}}$ & 5 & $9.43^{\mathrm{b}}$ & 31 & $58.49^{\mathrm{c}}$ & 15 & 28.30 & 0 & 0 \\
\hline \multicolumn{3}{|c|}{$\mathrm{p}$} & \multicolumn{2}{|c|}{0.01} & \multicolumn{2}{|c|}{0.03} & \multicolumn{2}{|c|}{0.04} & \multicolumn{2}{|c|}{ NS } & & \\
\hline
\end{tabular}

SF: small follicles group, LF: large follicles group. A: $5 \mu \mathrm{g} / \mathrm{ml} \mathrm{IGF}+5 \mathrm{mM}$ Glucose $+1 \mu \mathrm{g} / \mathrm{ml} \mathrm{GH}+50 \mu \mathrm{g} / \mathrm{ml} \mathrm{LH}, \mathrm{B}: 10 \mu \mathrm{g} / \mathrm{ml}$ IGF+ $5.5 \mathrm{mM}$ Glucose $+5 \mu \mathrm{g} / \mathrm{ml} \mathrm{GH}+100 \mu \mathrm{g} / \mathrm{ml} \mathrm{LH}$. Values for the same column with different letters are significantly different $(\mathrm{P}<0.05)$. NS: not significant.

\section{6- The meiotic progression at the 21- hour} time interval

After 21 hours of incubation, Table 7 indicates that oocytes across the different groups showed a significant difference in M-I $(p=0.01)$ with a superiority of matured oocytes in B solution (33.96\%; LF group), while the matured oocytes in A solution achieved the lowest values across SF and
LF groups $(12.00 \%$ and $14.00 \%$ respectively). Also, it was observed during this period that the oocytes began to enter the M-II with a statistically not significant difference despite the clear difference between the upper (13.46\%; B solution; LF group) and lower rates (2.00\%; A solution; SF group). 
Table 7. The meiotic progression of Awassi sheep oocytes in vitro cultured for 21 hours in TCM-199 according to the follicle size and maturation treatment

\begin{tabular}{|c|c|c|c|c|c|c|c|c|c|c|c|c|}
\hline \multicolumn{2}{|c|}{ Source } & \multirow{2}{*}{$\begin{array}{c}\text { Incubated } \\
\text { oocytes } \\
\text { No. }\end{array}$} & \multicolumn{10}{|c|}{ The phase of nuclear maturation } \\
\hline Follicle size & $\begin{array}{c}\text { Maturation } \\
\text { treatment }\end{array}$ & & \multicolumn{2}{|c|}{$\begin{array}{c}\text { G.V } \\
(\text { No. / \%) }\end{array}$} & \multicolumn{2}{|c|}{$\begin{array}{c}\text { GVBD } \\
(\text { No. /\%) }\end{array}$} & \multicolumn{2}{|c|}{$\begin{array}{l}\text { Pro M-I } \\
(\text { No. / \%) }\end{array}$} & \multicolumn{2}{|c|}{$\begin{array}{c}\text { M-I } \\
(\text { No. /\%) }\end{array}$} & \multicolumn{2}{|c|}{$\begin{array}{c}\text { M-II } \\
(\text { No. /\%) }\end{array}$} \\
\hline \multirow{2}{*}{ SF } & $\mathrm{A}$ & 50 & 12 & $24.00^{\mathrm{a}}$ & 12 & $24.00^{\mathrm{a}}$ & 19 & 38.00 & 6 & $12.00^{\mathrm{a}}$ & 1 & 2.00 \\
\hline & B & 50 & 7 & $14.00^{\mathrm{b}}$ & 12 & $24.00^{\mathrm{b}}$ & 19 & 38.00 & 7 & $14.00^{\mathrm{b}}$ & 5 & 10.00 \\
\hline \multirow{2}{*}{$\mathrm{LF}$} & $\mathrm{A}$ & 52 & 4 & $7.69^{b}$ & 4 & $7.69^{\mathrm{b}}$ & 23 & 44.23 & 15 & $28.84^{\mathrm{b}}$ & 6 & 11.53 \\
\hline & B & 53 & 1 & $1.88^{\mathrm{c}}$ & 1 & $1.88^{\mathrm{c}}$ & 26 & 49.05 & 18 & $33.96^{\mathrm{c}}$ & 7 & 13.46 \\
\hline \multicolumn{3}{|c|}{$P$} & \multicolumn{2}{|c|}{0.004} & \multicolumn{2}{|c|}{0.001} & \multicolumn{2}{|c|}{ NS } & \multicolumn{2}{|c|}{0.01} & \multicolumn{2}{|c|}{ NS } \\
\hline
\end{tabular}

SF: small follicles group, LF: large follicles group. A: $5 \mu \mathrm{g} / \mathrm{ml} \mathrm{IGF+} 5 \mathrm{mM}$ Glucose $+1 \mu \mathrm{g} / \mathrm{ml} \mathrm{GH}+50 \mu \mathrm{g} / \mathrm{ml} \mathrm{LH,} \mathrm{B:} 10 \mu \mathrm{g} / \mathrm{ml}$ IGF+ $5.5 \mathrm{mM}$ Glucose $+5 \mu \mathrm{g} / \mathrm{ml} \mathrm{GH}+100 \mu \mathrm{g} / \mathrm{ml} \mathrm{LH}$. Values for the same column with different letters are significantly different $(\mathrm{P}<0.05)$. NS: not significant.

\section{7- The meiotic progression at the 24- hour time interval}

Table 8 shows the results of the meiotic progression after 24 hours of maturation, as the rates of oocytes involved in the M-II were sub-intermediate and ranged between $20.00 \%$ and $36.00 \%$, but without any statistical significance. In this period, the oocytes continued their progression in M-I and achieved a relative increase in values which ranged between $30.00 \%$ and $58.00 \%$ $(\mathrm{p}=0.02)$.

The insignificant difference was evident in the GVBD and GVBD phases, where the rate of matured oocytes in $\mathrm{B}$ solution (LF group) decreased to $2 \%$, followed by the oocytes in solution A $(8.00 \%)$ for each group respectively.

Table 8. The meiotic progression of Awassi sheep oocytes in vitro cultured for 24 hours in TCM-199 according to the follicle size and maturation treatment

\begin{tabular}{|c|c|c|c|c|c|c|c|c|c|c|c|c|}
\hline \multicolumn{2}{|c|}{ Source } & \multirow[b]{2}{*}{$\begin{array}{c}\text { Incubated } \\
\text { oocytes } \\
\text { No. }\end{array}$} & \multicolumn{10}{|c|}{ Phase of nuclear maturation } \\
\hline Follicle size & $\begin{array}{c}\text { Maturation } \\
\text { treatment }\end{array}$ & & \multicolumn{2}{|c|}{$\begin{array}{c}\text { G.V } \\
(\text { No. / \%) }\end{array}$} & \multicolumn{2}{|c|}{$\begin{array}{c}\text { GVBD } \\
(\text { No. / \%) }\end{array}$} & \multicolumn{2}{|c|}{$\begin{array}{l}\text { Pro M-I } \\
(\text { No. / \%) }\end{array}$} & \multicolumn{2}{|c|}{$\begin{array}{c}\text { M-I } \\
(\text { No. } / \%)\end{array}$} & \multicolumn{2}{|c|}{$\begin{array}{c}\text { M-II } \\
(\text { No. /\%) }\end{array}$} \\
\hline \multirow{2}{*}{ SF } & A & 50 & 7 & 14.00 & 7 & 14.00 & 11 & $22.00^{\mathrm{a}}$ & 15 & $30.00^{\mathrm{a}}$ & 10 & 20.00 \\
\hline & B & 50 & 6 & 12.00 & 5 & 10.00 & 10 & $20.00^{\mathrm{b}}$ & 19 & $38.00^{\mathrm{b}}$ & 10 & 20.00 \\
\hline \multirow{2}{*}{$\mathrm{LF}$} & A & 50 & 4 & 8.00 & 4 & 8.00 & 4 & $8.00^{\mathrm{b}}$ & 24 & $48.00^{\mathrm{b}}$ & 14 & 28.00 \\
\hline & B & 50 & 1 & 2.00 & 1 & 2.00 & 1 & $2.00^{c}$ & 29 & $58.00^{\mathrm{c}}$ & 18 & 36.00 \\
\hline \multicolumn{3}{|c|}{$\mathrm{p}$} & \multicolumn{2}{|c|}{ NS } & \multicolumn{2}{|c|}{ NS } & \multicolumn{2}{|c|}{0.007} & \multicolumn{2}{|c|}{0.02} & \multicolumn{2}{|c|}{ NS } \\
\hline
\end{tabular}

SF: small follicles group, LF: large follicles group. A: $5 \mu \mathrm{g} / \mathrm{ml} \mathrm{IGF+} 5 \mathrm{mM}$ Glucose $+1 \mu \mathrm{g} / \mathrm{ml} \mathrm{GH}+50 \mu \mathrm{g} / \mathrm{ml} \mathrm{LH}, \mathrm{B}: 10 \mu \mathrm{g} / \mathrm{ml}$ IGF+ $5.5 \mathrm{mM}$ Glucose $+5 \mu \mathrm{g} / \mathrm{ml} \mathrm{GH}+100 \mu \mathrm{g} / \mathrm{ml} \mathrm{LH}$. Values for the same column with different letters are significantly different $(\mathrm{P}<0.05)$. NS: not significant. 


\section{8- The meiotic progression at the 27-hour}

\section{time interval}

At the end of the maturation period (27 hours), there was a significant difference in the rates of the M-II $(\mathrm{p}=0.002)$, as the matured oocytes in B solution showed a great superiority over their counterparts in the other groups $(84.61 \%$; LF group), In general, the rates of $\mathrm{M}-\mathrm{II}$ in this period across all groups of oocytes was high (> $56.00 \%$ ); however, there was still a significant difference in the rates of M-I (0.02), but with low rates values(25.49\% 7.69\%) (Table 9).

Table 9. The meiotic progression of Awassi sheep oocytes in vitro cultured for 27 hours in TCM-199

\begin{tabular}{|c|c|c|c|c|c|c|c|c|c|c|c|c|}
\hline \multicolumn{2}{|c|}{ Source } & \multirow[b]{2}{*}{$\begin{array}{c}\text { Incubated } \\
\text { oocytes } \\
\text { No. }\end{array}$} & \multicolumn{10}{|c|}{ Phase of nuclear maturation } \\
\hline Follicle size & $\begin{array}{c}\text { Maturation } \\
\text { treatment }\end{array}$ & & \multicolumn{2}{|c|}{$\begin{array}{c}\text { G.V } \\
\text { (No. } / \%)\end{array}$} & \multicolumn{2}{|c|}{$\begin{array}{c}\text { GVBD } \\
\text { (No. } / \% \text { ) }\end{array}$} & \multicolumn{2}{|c|}{$\begin{array}{c}\text { Pro M-I } \\
\text { (No. / \%) }\end{array}$} & \multicolumn{2}{|c|}{$\begin{array}{c}\text { M-I } \\
\text { (No. / \%) }\end{array}$} & \multicolumn{2}{|c|}{$\begin{array}{c}\text { M-II } \\
\text { (No. / \%) }\end{array}$} \\
\hline \multirow{2}{*}{ SF } & A & 51 & 3 & 5.88 & 3 & 5.88 & 3 & 5.88 & 13 & $25.49^{\mathrm{a}}$ & 29 & $56.86^{\mathrm{a}}$ \\
\hline & $\mathrm{B}$ & 52 & 3 & 5.76 & 2 & 3.84 & 3 & 5.76 & 14 & $26.92^{\mathrm{a}}$ & 30 & $57.69^{\mathrm{a}}$ \\
\hline \multirow{2}{*}{ LF } & A & 51 & 2 & 3.92 & 2 & 3.92 & 1 & 1.96 & 6 & $11.76^{\mathrm{a}}$ & 40 & $78.43^{\mathrm{b}}$ \\
\hline & $\mathrm{B}$ & 52 & 2 & 3.84 & 2 & 3.84 & 2 & 3.84 & 4 & $7.69^{\mathrm{b}}$ & 44 & $84.61^{\mathrm{c}}$ \\
\hline \multicolumn{3}{|c|}{$p$} & \multicolumn{2}{|c|}{ NS } & \multicolumn{2}{|c|}{ NS } & \multicolumn{2}{|c|}{ NS } & \multicolumn{2}{|c|}{0.02} & \multicolumn{2}{|c|}{0.002} \\
\hline
\end{tabular}

SF: small follicles group, LF: large follicles group. A: $5 \mu \mathrm{g} / \mathrm{ml} \mathrm{IGF+} 5 \mathrm{mM}$ Glucose $+1 \mu \mathrm{g} / \mathrm{ml} \mathrm{GH}+50 \mu \mathrm{g} / \mathrm{ml} \mathrm{LH}, \mathrm{B}: 10 \mu \mathrm{g} / \mathrm{ml}$ $\mathrm{IGF}+5.5 \mathrm{mM}$ Glucose $+5 \mu \mathrm{g} / \mathrm{ml} \mathrm{GH}+100 \mu \mathrm{g} / \mathrm{ml} \mathrm{LH}$.

Values for the same column with different letters are significantly different $(\mathrm{P}<0.05)$. NS: not significant.

\section{DISCUSSION}

The process of oocyte maturation includes two closely related stages: the cytoplasmic and the nuclear maturation. Cytoplasmic maturation is concerned with preparing the internal environment of the oocyte for the process of fertilization and entry of the sperm, while the nuclear maturation is associated with a set of sequential and successive changes, especially when the oocyte is in the dormant stage. When the appropriate conditions are available, the oocyte becomes activated, the nuclear envelope begins to break down (GVBD), the chromosomes condense and reach the M-I, and then to the M-II, where the nuclear maturation of the oocyte takes place. In our experiment, over the 27-hour maturation period, a general linear increase was observed from the GV stage to M-II with different rates of studied stages across the previous groups. Before incubation (0hour time interval), the collected oocytes of SF and LF groups showed a significant difference $(\mathrm{P}=0.01)$ in the rates of the $\mathrm{GV}$ and GVBD stages, as it was observed that a 
quarter of the harvested oocytes from the LF group were in the GVBD stage (Table 2). In references, very limited studies have dealt with the fracture of arrest and the continuation of the meiotic sequence of oocytes that are inside the follicle at the GV stage before ovulation. In fact, the presence of oocytes in the GVBD stage at the period of the collection in both groups of follicles can be due to a set of factors. But a very important factor is that relationship that governs the development of ovarian follicles and the atresia (degradation) of those follicles during the dynamic follicular wave system and the dominant follicle selection which leads to breaking the arrest of the oocytes in the atretic follicles and thus the resumption of meiosis within the follicle to advanced stages that may reach the stage of M-II (Gougeon and Testart, 1986).The period during collecting the ovaries, obtaining the oocytes and treatment before maturation is not considered sufficient evidence for the oocytes to resume meiosis following the $\mathrm{GV}$ stage (Barretto et al. 2011). Upon the oocyte collection period, Gougeon and Testart (1986) noticed that the rates of the GVBD stage ranged between $0 \%$ and $7 \%$, while the rates of $\mathrm{GV}$ stage ranged between $79 \%$ and $100 \% ; \mathrm{P}<0.05$. The study of Crocomo et al.
(2015) showed that the rates of GV stage ranged between $87.7 \%$ and $92.0 \%$, and between $6.2 \%$ and $10.7 \%$ for GVBD stage. The second time interval ( $3 \mathrm{~h})$ postincubation did not witness any significant changes in the successive meiosis across the four groups (Table 3), this is mainly due to the biological timing low of meiosis in reproductive cells (cell cycle). At the third time interval $(6 \mathrm{~h})$, the distributional activity of the oocytes was evident by entering the GVBD phase in the four groups, with a difference of approximately $20 \%$ between the two groups of SFand LF. However, the arrival of the oocytes to an amount of approximately half (SF and LF groups; A and B solutions) will not imply the influence of the factors included in the study because all oocytes showed an insignificant difference in the Pro M-I (Table 4). It can be said that the effect of the studied factors was evident in the subsequent time intervals extending between 21 and 27 hours (Tables 7, 8 and 9). Within the oocyte samples in our study, the vital functions of the studied factors differ in the meiotic activity, and perhaps the most two important parameters that can determine the effectiveness of these factors are the developmental competence of the oocyte and its direct correlation with its 
diameter as well as the developmental stage of the follicle. The reasons that led to obtaining the current results can be traced back to a group of issues, which can be summarized as follows: via cell signaling, the relationship between $I G F-1$ and MAPK can be elucidated by two pathways control the activation of the $I G F-1$ receptor (IGF$1 R)$ : the Ras/mitogen activated protein kinase (MAPK) pathway and the phosphoinositide 3-kinase (PI3K)/Akt pathway .Thus, the $I G F-1 R$ activates the insulin receptor substrate (IRS) protein and collagen homologues protein, stimulates Ras through a GTPase, and triggers a kinase cascade, eventually resulting in the activation of MAPK (phosphorylation) (Murphy and $\mathrm{Hu}, 2013$ ). Given that there are no LH receptors (LHR) surrounding the oocytes, LH probably play an important role in acting to induce GVBD by an indirect action mediated by cumulus cells (Dekel and beers, 1980; Dekel et al., 1988). $\mathrm{GH}$ is a major factor in the expansion of the cumulus cells, which in turn is the primary introductory process for initiating the processes of nuclear maturation (the deposition of a hyaluronan-rich extracellular matrix by the cumulus cells) (Marchal et al. 2003). At the level of mammalian oocytes, the primary vital role of glucose is that it enters the main energy component in the glycolysis, pentose phosphate pathway (PPP) and the tricarboxylic acid cycle (TAC) (Xie et al. 2016; Downs et al. 1996). When comparing the results of the current study with a study conducted by Crocomo et al. (2015) on sheep oocytes under the influence of roscovitine, a great convergence was observed in the rates of different stages (Table 10).

Table 10. Nuclear configuration of sheep oocytes cultured in vitro for 6,12 or $20 \mathrm{~h}$ in basic maturation medium (Control) supplemented with $75 \mathrm{M}$ roscovitine (Rosco). $0 \mathrm{~h}$ : COCs were aspirated with (Rosco) or without (Control) roscovitine and immediately stained. (Crocomo et al. (2015))

\begin{tabular}{llllll}
\hline & & \multicolumn{4}{l}{ Nuclear maturation stage, $n(\%)$} \\
\cline { 3 - 5 } Treatments & No. COC & GV & GVBD & MI & MII \\
\hline Control 0 h & 122 & $107(87.7)^{a, A}$ & $13(10.7)^{b, B}$ & $0(0.0)^{d, C}$ & $0(0.0)^{c, C}$ \\
Rosco 0 h & 113 & $104(92.0)^{a, A}$ & $7(6.2)^{b, B}$ & $0(0.0)^{d, B}$ & $0(0.0)^{c, B}$ \\
Control 6 h & 90 & $42(46.7)^{c, A}$ & $21(23.4)^{a, B}$ & $27(30.0)^{b, B}$ & $0(0.0)^{c, C}$ \\
Rosco 6 h & 98 & $85(86.7)^{a, A}$ & $13(13.3)^{b, B}$ & $0(0.0)^{d, C}$ & $0(0.0)^{c, C}$ \\
Control 12 h & 94 & $24(25.5)^{d, B}$ & $7(7.4) b)^{C, D}$ & $51(54.3)^{a, A}$ & $11(11.7)^{b, C}$ \\
Rosco 12 h & 109 & $71(65.1)^{b, A}$ & $11(10.1)^{b, B, C}$ & $11(18.4)^{b, c, B}$ & $4(3.7) b, c, C$ \\
Control 20 h & 103 & $15(14.6)^{e, B}$ & $9(8.7)^{b, B}$ & $10(9.7)^{c, d, B}$ & $63(61.2)^{a, A}$ \\
Rosco 20 h & 106 & $69(65.1)^{b, A}$ & $15(14.2)^{b, B}$ & $10(9.4)^{c, d, B, C}$ & $1(1.0)^{c, C}$ \\
\hline
\end{tabular}

Standard error $(\mathrm{SE})=0.037$ and coefficient of variation $(\mathrm{CV})=4.54 \%$ for the analysis. 
In a study in which a comparison was conducted to study the role of TCM-199 and the follicular fluid (FF) on nuclear maturation (Aguilar et al. 2007), a decrease in the rates of oocytes reaching different stages (0 and 36-40 -h time intervals) was observed compared to the results of our study (Table 11).

Table 11. Nuclear maturation patterns (percentages) of oocytes at Time 0 (Control) and after in vitro maturation in TCM-199 and follicular fluid for 36 to $40 \mathrm{~h}$ (Aguilar et al. 2007)

\begin{tabular}{cccccccccccccccc}
\hline \multicolumn{1}{c}{ Compact } & \multicolumn{1}{c}{ Expanded } \\
\hline & $\mathrm{n}$ & GV & MI & MII & Deg & n & GV & MI & MII & Deg & n & GV & MI & MII & Deg \\
\hline Control & 56 & $67.9^{\mathrm{a}}$ & $0.0^{\mathrm{a}}$ & $1.8^{\mathrm{a}}$ & $30.4^{\mathrm{ab}}$ & 22 & $59.1^{\mathrm{a}}$ & 13.6 & $9.1^{\mathrm{a}}$ & 18.2 & 19 & $84.2^{\mathrm{a}}$ & $5.3^{\mathrm{a}}$ & $0.0^{\mathrm{a}}$ & 10.5 \\
TCM-199 & 47 & $8.5^{\mathrm{b}}$ & $34.0^{\mathrm{b}}$ & $12.8^{\mathrm{b}}$ & $44.7^{\mathrm{a}}$ & 18 & $16.7^{\mathrm{b}}$ & 22.2 & $16.7^{\mathrm{ab}}$ & 44.4 & 17 & $5.9^{\mathrm{b}}$ & $47.1^{\mathrm{b}}$ & $17.6^{\mathrm{ab}}$ & 29.4 \\
FF & 44 & $2.3^{\mathrm{b}}$ & $45.5^{\mathrm{c}}$ & $31.8^{\mathrm{c}}$ & $20.5^{\mathrm{b}}$ & 16 & $0.0^{\mathrm{b}}$ & 25.0 & $43.8^{\mathrm{b}}$ & 31.3 & 26 & $0.0^{\mathrm{b}}$ & $38.5^{\mathrm{b}}$ & $26.9^{\mathrm{b}}$ & 34.6 \\
\hline a,b,c Different superscripts indicate statistical differences within columns (P < 0.05). Control: oocytes not matured in vitro. \\
FF: 100\% preovulatory follicular fluid. Deg: degenerated.
\end{tabular}

The results of our study also came in on the course of nuclear and cytoplasmic general agreement with a study that was maturation of porcine oocytes (Meinecke conducted to study the effect of $\alpha$-amanitin and Meinecke 1993; Table 12).

Table 12. Effect of $\alpha$-amanitin on nuclear maturation and cumulus expansion of porcine oocytes. Oocytes were first cultured for various periods in control medium, subsequently transferred to $\alpha$ amanitin supplemented medium and then maintained with the mRNA inhibitor until fixation $44 \mathrm{~h}$ alder explanation (Meinecke and Meinecke 1993)

\begin{tabular}{|c|c|c|c|c|c|c|}
\hline \multirow{2}{*}{$\begin{array}{l}\text { Duration of } \\
\text { culture (h) }\end{array}$} & \multirow{2}{*}{$\begin{array}{l}\text { Medium with } 10 \mathrm{Mtg} \alpha \\
\text {-amanitin } \mathrm{m} 1\end{array}$} & \multirow{2}{*}{$\begin{array}{c}\text { Oocytes } \\
\text { (No.) }\end{array}$} & \multicolumn{4}{|c|}{$\%$ of oocytes in } \\
\hline & & & $\mathrm{GV}$ & GVBD & M I & M II \\
\hline- & 44 & 90 & 95.6 & - & 3.3 & 1.1 \\
\hline 0.5 & 43.5 & 84 & 93.6 & - & 4.3 & 2.1 \\
\hline 1 & 43 & 85 & 96.5 & - & 3.5 & - \\
\hline 2 & 42 & 86 & 65.1 & 12.8 & 14 & 8.1 \\
\hline 4 & 40 & 157 & 46.5 & 7.6 & 31.8 & 14.1 \\
\hline 6 & 38 & 81 & 53.1 & 2.5 & 23.5 & 20.9 \\
\hline 8 & 36 & 71 & 40.8 & 5.6 & 45.1 & 8.5 \\
\hline 12 & 32 & 94 & 1.1 & - & 20.2 & 78.7 \\
\hline 20 & 24 & 97 & 7.2 & - & 14.4 & 78.4 \\
\hline 44 & - & 93 & 8.6 & - & 24.7 & 66.6 \\
\hline
\end{tabular}




\section{REFERENCES}

Aguilar, J., Mas, C., Reyley, Ludueña, M., Mouguelar, R., H., Losinno, L. 2007. Nuclear maturation and mitochondrial distribution in equine oocytes matured in vitro. Anim. Reprod, 4(3/4): 88-97.

Arat, S., Caputcu, AT., Cevik, M., Akkoc, T., Cetinkaya, G., Bagis, H. 2016. Effect of growth factors on oocyte maturation and allocations of inner cell mass and trophectoderm cells of cloned bovine embryos. Zygote, 24: 554-562.

Barretto, L.S.S., Castro, V.S.D.C., Garcia, J.M., Mingoti, G.Z. 2011. Meiotic inhibition of bovine oocytes in medium supplemented with a serum replacer and hormones: effects on meiosis progression and developmental capacity. Zygote, 19: 107-16.

Cetica, P., Pintos, L., Dalvit, G., Beconi, M.2002. Activity of key enzymes involved in glucose and triglyceride catabolism during bovine oocyte maturation in vitro. Reprod, 124: 675-681.

Crocomo, L. F., Marques Filho, W. C., Ackermann, C. L., Paschoal, D. M., Guastali, M. D., Dias Maziero, R. R., Bicudo, S. D. 2015. Time course of the meiotic arrest in sheep cumulus-oocyte complexes treated with roscovitine. Zygote, 24(2): 310-318. de Oliveira Bezerra, A., Nicacio, A.C., de Oliveira Menezes, G.R., da Costa Gomes, R., da Silva, L.O.C., de Souza Rocha-Frigoni, N.A., Mingoti, G.Z., da Silva Leão, B.C., da Costa e Silva, E.V., Nogueira É. 2019. Comparison between in vitro embryo production using Y-sorted sperm and timed artificial insemination with non-sorted sperm to produce crossbred calves. Anim Reprod Sci. 208:106-101.

Dekel, N., Beers, W.H. 1980.Development of rat oocyte in vitro: inhibition and induction of maturation In the presence or absence of the cumulus oophorus. Dev8iol75: 247-252.

Dekel, N., Galiani, D., Sherizly, I. 1988. Dissociation between the inhibitory and the stimulatory action of cAMP on maturation of rat oocytes. Mol Cell Endocrinol, 56: 115-121.

Downs, S.M., Humpherson, P.G., Martin, K.L., Leese, H.J. 1996. Glucose utilization during gonadotropin-induced meiotic maturation in cumulus cellenclosed mouse oocytes. Molecular reproduction and development, 44(1):121131.

Driancourt, M.A., Thuel, B. 1998. Control of oocyte growth and maturation by follicular cells and molecules present in 
follicular fluid. A review. Reprod Nutr Dev, 38: 345-362.

Gougeon, A., Testart, J. 1986. Germinal vesicle breakdown in oocytes of human atretic follicles during the menstrual cycle. Reproduction, 78(2): 389-401.

Lorenzo, P.L., Illera, M.J., Illera, J.C., Illera, M. 1994. Enhancement of cumulus expansion and nuclear maturation during bovine oocyte maturation in vitro by the addition of epidermal growth factor and insulin-like growth factor I. J Reprod Fertil 101: 697-701.

Marchal, R., Caillaud, M., Martoriati, A., Ge'rard, N., Mermillod, P., Goudet, G. 2003. Effect of Growth Hormone (GH) on In Vitro Nuclear and Cytoplasmic Oocyte Maturation, Cumulus Expansion, Hyaluronan Synthases, and Connexins 32 and 43 Expression, and GH Receptor Messenger RNA Expression in Equine and Porcine Species1. Biology of reproduction, 69: 1013-1022.

Mardenli, O., Mohammad, M.S., Alolo, A.Y. 2020b. Effect of Combination of Follicle Size, FSH and Cysteamine on In Vitro Production of Sheep Embryos. JITV, 25 (3): 131-138.

Mardenli, O., Mohammad, M.S., Hassooni, H.A. 2020a. Efficiency of Dimethyl Sulphoxide and Ethylene Glycol on Subsequent Development of Vitrified Awassi Sheep Embryos. JITV, 25 (2): 6067.

Meinecke, B., Meinecke-Tillmann, S. 1993. Effects of a-amanitin on nuclear maturation of porcine oocytes in vitro. Journal of Reproduction and fertility, 98: 195-201.

Murphy, C.T., Hu, P.J. Insulin/insulinlike growth factor signaling in C. elegans. In: Worm book.org, 1-43. http://www.wo rmbo ok.org/chapters/www_insulingrowth signal/insulingrowthsignal.pdf

Oberlender, G., Murgas, L.D.S., Zangeronimo, M.G., da Silva, A.C., Menezes, T.A., Pontelo, T.P., Vieira, L.A. 2013. Role of insulin-like growth factor-I and follicular fluid from ovarian follicles with different diameters on porcine oocyte maturation and fertilization in vitro. Theriogenology, 80: 319-327.

SAS Institute Inc. 2017. SAS/STAT® 14.3 User's Guide: High-Performance Procedures. Cary, NC 27513 (USA): SAS Institute Inc.

Sato,H., Iwata, H., Hayashi, T., Kimura, K., Kuwayama, T., Monji, Y.2007. The effect of glucose on the progression of the nuclear maturation of pig oocytes. Anim. Reprod. Sci, 99: 299-305. 
Sen, A.R., Caiazza, F. 2013. Oocyte Maturation: A story of arrest and release. Frontiers in Bioscience, 5(1): 451-477.

Spindler, R. E., Pukazhenthi, B.S., Wildt, D. E. 2000. Oocyte metabolism predicts the development of cat embryos to blastocyst in vitro. Mol. Reprod. Dev, 56: 163-171.

Steeves, T. E., Gardner, D. K. 1999. Metabolism of glucose, pyruvate, and glutamine during the maturation of oocytes derived from prepubertal and adult cows. Mol. Reprod. Dev, 54: 92-101.

Toori, M.A., Mosavi, E., Nikseresht, M., Barmak, M.J., Mahmoudi, R. 2014. Influence of insulinlike growth factor-I on maturation and fertilization rate of immature oocyte and embryo development in NMRI mouse with TCM199 and alphaMEM medium. J Clin Diagn Res, 8: AC05AC08.
Wasielak, M., Bogacki, M.2007. Apoptosis inhibition by insulin-like growth factor (IGF)-I during in vitro maturation of bovine oocytes. J Reprod Dev, 53: 419426.

Xie, H.L., Wang, Y.B., Jiao, G.Z., Kong, D.L., Li, Q., Li, H., et al. 2016. Effects of glucose metabolism during in vitro maturation on cytoplasmic maturation of mouse oocytes. Scientific reports, 6:20764. 